\title{
Pre-Service Primary Teachers' Opinions on Team-Games-Tournaments
}

\author{
Aşkın Baydar ${ }^{1}$ \\ ${ }^{1}$ Faculty of Education, Artvin Çoruh University, Artvin, Turkey \\ Correspondence: Aşkın Baydar, Faculty of Education, Artvin Çoruh University, Artvin, Turkey. E-mail: \\ askinbaydar@artvin.edu.tr
}

Received: July 7, 2020

doi:10.5539/ies.v14n1p86
Accepted: September 24, 2020

Online Published: December 26, 2020

URL: https://doi.org/10.5539/ies.v14n1p86

\begin{abstract}
The aim of this study is to determine pre-service primary teachers' opinions regarding the implementation of teams-games-tournaments (TGT). For this purpose, the action research method, which is one of the qualitative research methods, was employed. The study group in the research consisted of 30 students who attended Artvin Çoruh University College of Education Elementary Education Department Primary School Teaching Program. Qualitative data was collected by interview forms with open-ended questions. With the answers the participants gave to the interview questions, they shared their opinions about advantages and disadvantages of the method and their suggestions about using the method in their future classes. Participants found positive interdependence and learning in heterogeneous groups, which are among the common features of cooperative learning, useful and necessary. Participants also stated the features of causing noise, making classroom management more difficult, sharing responsibility and rewards unfairly, and difficulty of implementing the method in crowded classes as disadvantages of the method.
\end{abstract}

Keywords: cooperative learning, teams-games-tournaments, classroom teaching, teacher education

\section{Introduction}

The positive effects of cooperative learning methods on learning environments are proven in many studies. Besides increasing academic achievement, cooperative implementations in classrooms provide great contributions to student's development in many aspects. For example, Kagan (1989) concluded that cooperative learning has positive effects on participation, listening, inductive and deductive reasoning, helping each other, sharing, concept development, communication, evaluation, application, peer teaching, analysis, synthesis, studying, solving, and presentation skills in his study. In Açıkgöz's (1993) study with pre-service teachers, and in Kasap's (1996) study of a secondary school third grade science course, it was found that cooperative learning has positive effects on retention. According to Sharan and Sharan (1990) cooperative learning improves social interaction, and according to Johnson and Johnson (1999), it improves high level reasoning, problem solving, critical thinking, communication skills, understanding each other's viewpoints, self-confidence, productivity, autonomy, positive self-identity, self-efficacy, self-control, and psychological health. According to Roger and Johnson (1994), it increases acceptance of differences and respect for others' views. Researchers also stated that cooperative learning is useful for attendance, learning transfer, moral reasoning, emotional health, internalization of values (Laatsch-Lybeck, 2000), creativity (Roger \& Johnson, 1994), developing positive attitudes towards the course (Muhammad, 2010), intrinsic motivation (Ning \& Hornby, 2013), positive attitude towards team work, studying effectively with others, empathy, conflict resolution, collective decision making (Thomas, 2014), analytical thinking (Choi \& Rhee, 2014), learning style (Weiss, Kramarski, \& Talis, 2006), and learning strategy identification (Liao, 2005; Topping, 2005). In the studies regarding students' opinions about implementations of collaborative learning, these methods were found to be similar to solving real life problems (Ediger, 2001), enjoyable and fun (Yalçın, 2008; Than Pham, 2013).

Teams-games-tournaments (TGT) is similar to student teams-achievement divisions (STAD) which is one of the most commonly used cooperative methods (Zetty, 1992). TGT is different from STAD with inter-group competition in tournaments (Bayrakçeken, Doymuş, \& Doğan, 2013). According to Slavin (1978), to implement TGT in class students are assigned to four- or five-member groups heterogeneously. The course subject is presented by the teacher to the whole class. During this process, the teacher can use all the techniques that the expository teaching strategy requires. After the teacher's presentation, worksheets are handed out to the groups and students work on the worksheets. During this work, the teacher works as a guide and only when guidance is 
necessary. Finishing the study, tournament desks are set up. The students are distributed to these desks homogeneously regarding achievements. For this, one student is allotted from each group to represent their own group. The teacher asks the questions prepared beforehand. According to the points given for the answers, the groups are ranked.

Studies regarding TGT's impacts in learning environments show similar results to the results for other cooperative learning methods. Ke and Grabovski (2007) found the method's positive effects on fifth graders, and Salam, Hossain, and Rahman (2015) found effects on eighth graders' attitudes towards mathematics. Paino (2001) stated that students like intergroup competition in TGT. Also other researchers stated that TGT is useful in terms of friendship, liking school, self-esteem (Slavin \& Karweit, 1981), improving peer tutoring (Slavin, 1975), affects opinions about teaching, intrinsic values, and self-efficacy positively (Tombak \& Altun, 2016), and increases motivation towards learning (Nadrah, Tolla, Ali, \& Muris, 2017), communication skills (Veloo, Md-Ali, \& Chairany, 2016), student satisfaction (González, Jennings, \& Manriquez, 2014), peer relations (Harmandar \& Çil, 2008), individual and social reliance (Şahin, 2011), and anger management (Wodarski \& Feit, 2011).

As seen, TGT affects many skills in different teaching levels and different courses. In research about how such an effective method is perceived by its future implementers, which aspects are effective, and which difficulties are faced with during the implementations, Mutlu (2018), Tombak and Altun (2016), and González et al. (2014) studied college students from different departments, Şimşek and Baydar (2019) studied social studies preservice teachers, and Şahin (2011) studied Turkish preservice teachers. In this study, TGT was implemented during six weeks in social science teaching lessons for pre-service primary education teachers and opinions about the applicability of the method were obtained. As a result, the aim of the research was to determine the opinions of pre-service primary teachers about the cooperative learning method of TGT.

\section{Method}

To gather the opinions of pre-service primary teachers about the implemented method, to determine the problems during implementation and to produce solutions to these problems (Yıldırım \& Şimşek, 2005), the action research design was chosen.

\subsection{Study Group}

A total of 30 pre-service teachers who attended Artvin Çoruh University primary school education during the 2017-2018 academic year participated in the study.

\subsection{Data Collection Tool}

Qualitative data in the research was collected with interview forms containing four open-ended questions. To provide the content and scope validity, opinions of three faculty members who are experts in the area were obtained. Participant answers to the interview questions were returned to five participants, who were selected randomly, for member checking, which is the most practical method to increase reliability in qualitative research (Büyüköztürk, Kılıç Çakmak, Akgün, Karadeniz, \& Demirel, 2012).

\subsection{Data Analysis}

The participants were given 40 minutes to fill out the interview form. Sample statements of the participants were underlined, coded and tabulated with frequency values. In the stage of interpreting data, statements by participants were exemplified with direct citations. Instead of giving the participants' real names, codes were used like S1, S2.

\subsection{Implementation}

The method was implemented in the social studies teaching course during six weeks. Before starting the lesson, the participants were divided in six heterogeneous groups based on their average grades from the previous semester. Each week the lesson started with the researcher's presentation about the content. After this presentation, work sheets were handed out to the participants and they were given 30 minutes to get ready for the tournament. In the tournament stage, "tournament tables" were created by taking one person from each group. Questions prepared beforehand were asked to the participants. The points for each group, given for the right answers, were summed and the groups were placed in achievement order.

\section{Results}

In this section, participants' answers to the interview questions are presented as tables. Coded participant statements and frequency tables are supported with direct quotations from participant answers. 
Table 1. Opinions of participants pertaining to the first interview question

\begin{tabular}{lr}
\hline Statements & $\mathrm{f}$ \\
\hline Gives self-confidence & 13 \\
Positive interdependence leads to achievement & 9 \\
Student learns entertainingly & 6 \\
Teamwork is useful & 3 \\
Makes knowledge more permanent & 12 \\
Learning occurs better in heterogeneous groups & 4 \\
Peer tutoring is useful & 6 \\
Appropriate for primary school students & 4 \\
Appropriate for secondary school students & 3 \\
Appropriate for all age groups & 3 \\
Appropriate for all courses & 4 \\
Provides democratic education & 2 \\
Competition is useful & 2 \\
Creates a group spirit & 4 \\
Provides active learning & 8 \\
Eliminates misconceptions & 2 \\
Improves communication skill & 7 \\
Improves sense of responsibility & 5 \\
Makes learning easier & 3 \\
Provides cognitive, affective, and social development & 3 \\
Improves participation & 3 \\
Improves empathy skills & 3 \\
\hline
\end{tabular}

The first interview question was "what are your positive opinions about TGT?" Most importantly, the participants thought that TGT would improve student's self-confidence. Some participant opinions are given below as examples:

S1: "Because kids are chosen from a group and represent their teams, talking in the community and knowledge sharing skills develop. In this way, the kid becomes a self-confident individual."

S3: "Because of the responsibilities given in the course, they would have a right to speak, and does their job in knowledge sharing and gains self-confidence."

S10: "Students' self-confidence increases because of successfully asking and answering effectively."

S17: "Talking about each other's opinions and listening mutually prevents them from being shy. The points obtained with the knowledge of the friend who leaves the group that week provides self-confidence."

Additionally, some participants declared counter opinions. For example, S12 said: "this method would cause a lack of confidence for students who don't know the right answers."

According to the pre-service teachers, TGT affects achievement in courses positively and in different ways. It increases retention of knowledge, makes learning easier, provides effective learning, and teaches entertainingly. Some of the participants' opinions are listed as follows:

S4: "Learning is permanent and quick because it occurs in the same age groups and friendly environment."

S15: "Student enjoys learning by sharing. So, knowledge becomes permanent."

S27: "Students come together and study by helping each other to learn. In this way they achieve more permanent and solid knowledge."

S15: "Different activities in classes make learning easier. A strong connection is established between new and old knowledge and misconceptions are eliminated."

S17: "If everybody is active in the process, learning becomes active."

S11: "As well as learning entertainingly, the student does not get bored in the class."

Participants' opinions about the characteristics of the method which can be counted as common characteristics of cooperative studies are generally positive. In general, they think that positive interdependence, setting up the groups heterogeneously, peer tutoring, and competition between groups are useful and necessary. Some 
participants' opinions are given below:

S1: "Learns through information exchange with the friends in group."

S2: "To reach success at the end of the activity, combining all efforts, in other words positive interdependence is necessary."

S17: "One member's knowledge deficiency causes loss of points for the group. Thus, everybody in the group is active."

S22: "One for all, all for one notion is present. And this notion leads to success."

S30: "Every student in the group is responsible for each other's learning which contributes to common success."

S3: "Peer teaching occurs more easily as the groups have heterogeneous structure."

S20: "Competition increases learning speed."

Some of the pre-service teachers consider TGT for primary grades, and others consider it for secondary grades. Besides some who think that the method is appropriate for all courses, some of them think that it is not. Here are some examples of participant opinions:

S28: "Perfect method especially for primary school. Appropriate for teaching simple knowledge with slight competition."

S15: "I recommend applying this method in other courses, because it can be applied in almost all courses."

S30: "I don't think it can be applied in all courses. When they learn from each other they might misunderstand and mistransfer."

According to the participants, TGT affects necessary developmental skills in the learning environment. They explain how this effect occurs as follows:

S3: "When the individual brings a point to his group by fulfilling his responsibility and receives praise with his group instead of individually, he feels the group mind."

S8: "Everybody's duty is different in the group. This improves sense of responsibility."

S16: "Individuals have to do their job. So, sense of responsibility improves."

S16: "This method contributes to individuals' cognitive, social and affective development."

S22: "With this method, we see that not only the individual's cognitive development, but also social and affective development are important."

S15: “... it seems that it also affects terminating communication deficiencies."

S16: "Communication between individuals increases."

S19: "It establishes and continues effective communication between groups or in groups."

Pre-service primary teachers think that group studies are useful in general. Besides the developments in many areas, cognitive development is also provided with TGT. According to the pre-service teachers, the method improves participation. Thus, it provides democratic education. During implementation students emotionally put themselves in each other's shoes and accordingly their empathy skills improves.

Table 2. Opinions of participants pertaining to the second interview question

\begin{tabular}{ll}
\hline Statements & $\mathrm{f}$ \\
\hline Causes loss of self-confidence & 5 \\
Causes conflict & 4 \\
Understanding does not occur for every student & 3 \\
Affects classroom management negatively & 7 \\
Authority gap occurs & 4 \\
Not appropriate for every course & 5 \\
Unfair for successful students & 1 \\
Noisy & 5 \\
Difficult to apply in crowded classrooms & 6 \\
\hline
\end{tabular}

In the answers to the second interview question, 'what are your negative opinions about TGT?', the participants 
expressed disadvantages of the method. According to the participants during the implementation conflicts could occur with the effects of competition. Classroom management gets more difficult. To avoid this situation, teachers should be more authoritative. Also, the teacher's presence is important as a knowledgeable authority. One of the critiques that came from the participants is that like other cooperative methods, students learn subjects only in their area of responsibility; thus, all subjects cannot be learnt by the whole group. Some participants' opinions regarding this issue are given below:

S2: "Group studies might cause the use of bad language to the rivals."

S3: "Students might not understand the subject not in their area of responsibility."

S7: "Teachers might have difficulty with classroom management."

S2: "Teachers should make provision for preventing conflicts."

S14: "In terms of certainty of knowledge, the interventions of teacher, who is the guide and authority on the issue, are important."

S20: "At the very end of the activity, the teacher's affirmation of knowledge and summary of the topic is important."

S21: "In conflicts, the teacher should get involved immediately and make the class aware of their authority."

S16: "If everybody receives the same points in the group, in case of failure, successful students could be discouraged."

S21: "In crowded classrooms the groups will be crowded. So, during the implementation some students will be passive. Also, it will be noisy."

\section{S25: "If there are too many groups, working would be very difficult."}

Critiques towards TGT are the same critiques that are made for all cooperative methods. For example, all group members receive the same points and heterogeneous structure of the groups are seen as unjust for successful students. The participants think that TGT is not appropriate for all courses or subjects.

Table 3. Opinions of participants pertaining to the third interview question

\begin{tabular}{lc}
\hline Statements & f \\
\hline Yes, competition makes learning faster (learns in more detail and willingly) & 5 \\
Yes, learning from a friend is easier & 4 \\
Yes, it improves social skills in addition to achievement & 7 \\
No, competition affects student negatively & 1 \\
No, classrooms are not suitable to implement the method & 3 \\
No, everybody doesn't study equally & 2 \\
No, everybody doesn't shoulder responsibility equally & 1 \\
No, it takes so much time & 2 \\
No, difficult to apply in crowded classrooms & 2 \\
No, it's so noisy & 3 \\
\hline
\end{tabular}

The third interview question was "would you use this method in your future classes, and why?" Pre-service teachers' answers to first part of this question are almost half and half. Sixteen participants started their answer was "yes"; and 14 participants said "no". Despite this, as seen in Table 3, the reasons for saying yes are grouped in only three items, while those who said no had more diverse reasons. Those who said yes emphasized more about the benefits of competition on learning speed, advantages of peer-tutoring and improvement of social skills besides academic achievement. Those who said no mentioned about competition's negative effects on learning, and factors that affect classroom management negatively like difficulty of application in crowded classrooms, noise, and unsuitability of classrooms for group studies. Because of the similarity of the participants' answers to the third interview question and the statements in Table 3, there are no one-to-one statements written separately. 
Table 4. Opinions of participants pertaining to the fourth interview question

\begin{tabular}{lc}
\hline Statements & $\mathrm{f}$ \\
\hline Improves problem-solving skills & 7 \\
Teamwork is useful & 3 \\
Improves the skill of helping each other & 12 \\
Gives self-confidence & 13 \\
Improves research skills & 5 \\
Improves sharing skills & 7 \\
Improves self-expression skills & 6 \\
Constructs group mind & 2 \\
Provides active learning & 8 \\
Improves communication skills & 7 \\
Improves sense of responsibility & 6 \\
Learns respect & 3 \\
Makes learning easier & 3 \\
Provides cognitive, affective and social development & 3 \\
Improves participation & 5 \\
Improves discussion skills & 4 \\
Improves asking skills & 2 \\
Improves empathy skills & 7 \\
Learn to criticize & 4 \\
\hline
\end{tabular}

The fourth interview question was "how do you evaluate the effect of the method in terms of individual and social development?" As seen, pre-service teachers think that TGT is useful for many individual and social zones of development. They declared their opinions about problem solving, helping each other, asking, self-expression, and criticism skills as follows:

S28: "They seek solutions to the problems they encounter together. Thus, problem-solving skills are improved."

S1: "The group prepares the student. They help each other. So, their helping skills are improved."

S2: "Cooperation is very important in the team. Because, team power is the real power. And this ensures they help each other in the group and increases children's interaction."

S17: "They reach conclusions by getting help from each other and prepare their friend who will represent them."

S30: "Everybody is responsible for each other's learning. This improves cooperation skills."

S2: "This method teaches better compared with expository teaching. The student learns by searching themselves."

S3: "They research about the topic from the sources, so they reach knowledge themselves."

S28: "... encourages research."

S5: "This method increases the sense of helping among individuals."

S13: "It increases helping and solidarity."

S4: "In this method achievement is not individualistic. The student expresses themselves without hesitation with the power of being a team member. They participate with more courage and self-confidence."

S6: "They find the opportunity to express their opinions and thoughts openly."

S18: "It improves student's asking and answering skills."

S26: "It gives students criticism and evaluation power."

Pre-service teachers believe in the advantages of working in groups and think that group studies construct team spirit. Cooperative studies done with team spirit provide cognitive, affective and social development. Learning gets easier, occurs actively, students share more, become self-confident, responsible, respectful, and active participants. The participants also think that TGT provides a big contribution to students' individual and social development by ensuring active learning, and improving communication and discussion skills.

\section{Discussion}

In this study after implementing TGT in a social studies course, pre-service teachers' opinions were obtained. Results were found that offer insight into implementing cooperative studies in classroom environments. When 
these results are examined in detail, in the literature some examples regarding cooperative learning and TGT support what pre-service teachers said in our study, while some examples do not.

The participants' statements about how students would gain self-confidence with the method similarly are found in studies by Topping (2005), Roger and Johnson (1994), Johnson and Johnson (1999), Bilgin, Aktaş, and Çetin (2014), Artut and Tarım (2007), and Doymuş, Şimşek, and Bayrakçeken's (2004). Some participants, on the other hand, expressed the view that students might lose their self-confidence with this method. This point of view is also supported by Artut and Tarım's (2007) study. The participants emphasized positive interdependence which is one of the important components of cooperative learning in general. Similarly, positive interdependence was viewed as necessary in cooperative applications by participants in Aydın's (2013) study. In the study by Marks and O'Connor's (2013), sharing success or failure with group members was mentioned and positive interdependence was emphasized. Participants in many similar studies stated that TGT is an enjoyable method, and students learn entertainingly with TGT (Thanh Pham, 2013; Yalçın, 2008; Ediger, 2001; Bilgin et al., 2014; Artut \& Tarım, 2007; Aydın, 2013; Demir, 2012; Doymuş, Şimşek, \& Bayrakçeken, 2004; Özbuğutu \& Hasenekoğlu, 2013; Uysal, 2010). The participants who mentioned the advantages of teamwork are supported by Marks \& O'Connor (2013), Thomas (2014), Topping (2005), and Aydın's (2013) studies. According to our participants, TGT affects knowledge retention positively. There are similar findings in Bilgin et al. (2014), Artut and Tarım (2007) and Demir (2012).

In contrast with the participants in the study by Marks and O'Connor's (2013), our participants found heterogeneous structures in cooperative learning groups. While Schniedewind and Davidson (2000) supported this view, Johnson and Johnson (1999) emphasized the positive relations in heterogeneous groups, and respect to handicaps and differences. Regarding this issue as expressed in the statement in Yeşilyurt's (2009) study, if people with different qualifications coexist, original products are produced. The emphasis made by our participants on peer tutoring, which is one of the important components of cooperative learning, is supported by Yeşilyurt's (2009) study. While some of the pre-service teachers, like in Artut and Tarım's (2007) study, found the method applicable in all courses, some of them, like in Demir's (2012) study, think that it is not appropriate for every course or subject. Again, similar to the participants in the study by Artut and Tarım's (2007) who said that the method provides a democratic learning environment, and similar with Kagan (1989) and Bilgin et al. (2014) who emphasized that the method improves participation, participants in this study also expressed the contribution of the method to democratic education. In contrast with this situation, some of our participants stated that during the activities, teachers should be authoritative. Similarly, the participants in Aydın's (2013) study stated the necessity of the teacher to participate in the activities more. These statements show that our students will not easily pass on more democratic methods from traditional methods.

As explained in the implementation section, one of the characteristics of TGT is students who are in cooperation within the group, and in competition among the groups. Accordingly, some participants mentioned about the advantages of the competition that the method requires. With this finding this study supports Bilgin et al.'s (2014) study. Besides, our participants emphasized that active learning is provided by TGT. With this aspect, our study is in the compatible with studies by Laatsch-Lybeck (2000), Topping (2005), Bilgin et al., (2014), and Özbuğutu and Hasenekoğlu's (2013). According to our participants, TGT improves communication skills. There are similar findings in Choi and Rhee (2014), Thomas (2013), Yalçın (2008), Topping (2005), Roger and Johnson (1994), Johnson and Johnson (1999); Kagan (1989), and Doğan, Uygur, Doymuş and Karaçöp (2010). Making learning easier is another feature of TGT present in the participants' statements. This feature is found in much research regarding cooperative learning (Yeşilyurt, 2009; Artut \& Tarım, 2007; Aydın, 2013; Doymuş, Şimşek, \& Bayrakçeken, 2004). Moreover, it is stated that with the implemented cooperative methods, students like the course subject more (Topping, 2005), and think at high levels (Johnson \& Johnson, 1999).

In our study, in parallel with Schniedewind and Davidson (2000), Kagan (1989), Bilgin et al., (2014), Aydın, (2013), Dishon and O'Leary (1984), the participants stated that the method provides cognitive, affective, and social development. Likewise, the statement that the method improves empathic skills is also found in studies by Thomas (2013), Roger and Johnson (1994), and Johnson and Johnson (1999). The participants stated that with this method students learn respect, like in Laatsch-Lybeck (2000), and Aydın's (2013) studies. Some participants are of the opinion that some discussions during activities cause conflict. While Bilgin et al.'s (2014) study supports this situation, in studies by Thomas (2013) and Kagan's (1989), contrarily, it was determined that cooperative learning leads to conflict resolution. In the study, the participants expressed the idea, which is supported by Kagan (1989), and Bilgin et al. (2014), that the method makes use of concepts in true ways.

One of the critiques of cooperative methods of being too noisy is mentioned by our participants as well for TGT. Yalçın (2008), Bilgin et al. (2014), and Artut and Tarım's (2007) studies are coincide about this issue. Again, the 
statements of our participants about the difficulty of implementing TGT in crowded classrooms are also found in Bilgin et al.'s (2014) study. According to our participants, like many other skills improved by cooperative learning, the discussion skill, which is mentioned about in Uysal's (2010) study, is also improved by TGT. Criticism skills are one of the skills improved by cooperative learning and mentioned in Choi and Rhee (2014) and Johnson and Johnson's (1999) studies. Similar findings regarding improvement of helping each other and sharing skills are also exist in Kagan (1989), Bilgin et al. (2014), Artut and Tarım (2007), Aydın (2013), and Uysal (2010). In a similar way, the findings regarding research skills overlap with the findings of Doğan et al. (2010), Gürbüz, Çakmak, and Derman (2012), and Uysal's (2010) studies; and the findings regarding self-expression skills overlap with findings of Artut and Tarım (2007), Aydın (2013), and Doğan et al.’s (2010) studies.

Pre-service teachers' opinions about TGT's positive effects on the problem-solving skill are compatible with the participant opinions in Johnson and Johnson (1999), and Aydın's (2013) studies. Furthermore, as in this study, positive effects of cooperative learning on analytical thinking were mentioned in Choi and Rhee's (2003) study. Similar to our participants, the participants of Ediger's (2001) study found similarities between the problems in cooperative learning to the problems in the real life.

In general, TGT had a positive effect on pre-service teachers. Even though some participants declared opposite opinions, in general they think that the method is applicable in their future classes, effective in several learning domains, and appropriate to improve several skills. Besides, complaints about other studies in cooperative groups in general, were stated for TGT as well. The major examples of these complaints are the ones about the problems raised by responsibility sharing. Also, noise, difficulty with classroom control and difficulty with implementation in crowded classes are some of the negative critiques that participants made about the method.

An important limitation of the research is that it was performed with pre-service teachers in 3rd year. The pre-service teachers answered the interview questions based on their experiences of the implementation in class. However, the third question was about implementation of the method in future classrooms; in other words, related to their lives as teachers. As pre-service teachers dominantly have practical lessons in primary schools in fourth year, they answered this question without having sufficient experience of the field. Repeating the study in a lesson in the second semester of fourth year may provide more realistic feedback.

In future studies, pre-service teachers can try different cooperative methods. By doing so, they will have the opportunity to make connections between their own implementations and their future teaching environment, and to test their opinions.

\section{References}

Açıkgöz, K. (1993). İşbirliğine dayalı öğrenme ve geleneksel öğretimin üniversite öğrencilerinin akademik başarısı, hatırda tutma düzeyleri ve duyuşsal özellikleri üzerindeki etkileri. A.Ü. Eğitim Bilimleri Fakültesi: 1. Ulusal Eğitim Bilimleri Kongresi, 187-201. Ankara: MEB Yayınları.

Artut, P. D., \& Tarim, K. (2007). The effectiveness of jigsaw II on prospective elementary school teachers. Asia-Pacific Journal of Teacher Education, 35(2), 129-141. https://doi.org/10.1080/13598660701268551

Aydın, F. (2013). Coğrafya bölümü öğrencilerinin bölgesel coğrafya dersinde işbirlikli öğrenme uygulamalarına ilişkin görüşleri ve öz değerlendirmeleri. Kuram ve Uygulamada Eğitim Bilimleri, 13(4), 2401-2418. https://doi.org/10.12738/estp.2013.4.1641

Bayrakçeken, S., Doymuş, K., \& Doğan, A. (2013). İşbirlikli öğrenme modeli ve uygulanması. Ankara: Pegem Akademi Yayınları.

Bilgin, İ., Aktaş, İ., \& Çetin, A. (2014). İşbirlikli Öğrenme Teknikleri Hakkında Öğretmen ve Öğrenci Görüşlerinin Karşılaştırmalı Olarak İncelenmesi. Bartın Üniversitesi Eğitim Fakültesi Dergisi, 3(2), 334-367. https://doi.org/10.14686/BUEFAD.201428188

Büyüköztürk, Ş., Kılıç-Çakmak, E., Akgün, Ö. E., Karadeniz, Ş., \& Demirel, F. (2012). Bilimsel araştırma yöntemleri (Geliştirilmiş 11. baskı). Ankara: Pegem Akademi.

Choi, B. K., \& Rhee, B. S. (2014). The influences of student engagement, institutional mission, and cooperative learning climate on the generic competency development of Korean undergraduate students. Higher Education, 67(1), 1-18. https://doi.org/10.1007/s10734-013-9637-5

Demir, K. (2012). An evaluation of the combined use of creative drama and jigsaw II techniques according to the student views: Case of a measurement and evaluation course. Procedia-Social and Behavioral Sciences, 47, 455-459. https://doi.org/10.1016/j.sbspro.2012.06.680

Dishon, D., \& O'Leary, P. W. (1984). A Guidebook for Cooperative Learning: A Technique for Creating More 
Effective Schools. Publication Sales, Learning Publications, Inc., PO Box 1326, Holmes Beach, FL 33509.

Doğan, A., Uygur, E., Doymuş, K., \& Karaçöp, A. (2010). The use of jigsaw technique in 7th grade primary science and technology course and students' views on this technique. Journal of Education Faculty, 12(1), 75-90.

Doymuş, K., Şimşek, Ü., \& Bayrakçeken, S. (2004). İşbirlikçi öğrenme yönteminin fen bilgisi dersinde akademik başarı ve tutuma etkisi. Türk Fen Eğitimi Dergisi, 1(2), 103-115.

Ediger, M. (2001). Cooperative learning versus competition: Which is better? Journal of Instructional Psychology, 23(3), 204-209.

González, A., Jennings, D., \& Manriquez, L. (2014). Multi-faceted impact of a team game tournament on the ability of the learners to engage and develop their own critical skill set. International Journal of Engineering Education, 30(5), 1213-1224.

Gürbüz, H., Çakmak, M., \& Derman, M. (2004). Çevre eğitiminde jigsaw tekniği kullanımının öğrencilerin akademik başarısına etkisi ve öğrencilerin bu tekniğe ilişkin görüşleri. Karadeniz Sosyal Bilimler Dergisi, $4(7)$.

Harmandar, M., \& Çil, E., (2008). The effects of science teaching through team game tournament technique on success levels and affective characteristics of students. Journal of Turkish Science Education, 5(2), 26.

Johnson, D. W., \& Johnson, R. T. (1999). What makes cooperative learning work. In JALT Applied Materials, 23-26. Tokyo: Japan Association for Language Teaching.

Kagan, S. (1989). The structural approach to cooperative learning. Educational Leadership, 47(4), 12-15.

Kasap, H. (1996). İşbirlikli öğrenme, fen başartsl, hatırda tutma, öğrenci yüklemeleri ve işbirlikli ögrenme gruplarındaki etkileşim. Yayınlanmamış yüksek lisans tezi. Dokuz Eylül Üniversitesi Sosyal Bilimler Enstitüsü, İzmir.

Ke, F., \& Grabowski, B. (2007). Gameplaying for maths learning: cooperative or not? British Journal of Educational Technology, 38(2), 249-259. https://doi.org/10.1111/j.1467-8535.2006.00593.x

Laatsch-Lybeck, L. J. (2000). Effects on cooperative learning on achievement and attitudes toward teamwork in medical technology students (Doctoral dissertation, Marquette University, Milwaukee).

Liao, H. C. (2005). Effects of cooperative learning on motivation, learning stragegyutilization, and grammar achievement of English language learners in Taiwan (Doctoral dissertation, University of New Orleans, New Orleans).

Marks, M. B., \& O'Connor, A. H. (2013). Understanding students' attitudes about group work: What does this suggest for instructors of business? Journal of Education for Business, 88(3), 147-158. https://doi.org/10.1080/08832323.2012.664579

Muhammad, Z. (2010). Effects of cooperative learning intervention on mathematics achievement outcomes and attitudes of non-science college majors (Doctoral dissertation, Southern University and A \& M College).

Mutlu, A. (2018). Comparison of two different techniques of cooperative learning approach: Undergraduates' conceptual understanding in the context of hormone biochemistry. Biochemistry and Molecular Biology Education, 46(2), 114-120. https://doi.org/10.1002/bmb.21097

Nadrah, N., Tolla, I., Ali, M. S., \& Muris, M. (2017). The effect of cooperative learning model of teams games tournament (TGT) and students' motivation toward physics learning outcome. International Education Studies, 10(2), 123. https://doi.org/10.5539/ies.v10n2p123

Ning, H., \& Hornby, G. (2014). The impact of cooperative learning on tertiary EFL learners' motivation. Educational Review, 66(1), 108-124. https://doi.org/10.1080/00131911.2013.853169

Özbuğutu, E., \& Hasenekoğlu, Ġ. (2013). Bitkisel dokular konusunda işbirliğine dayalı öğretim yönteminin etkililiğine yönelik öğrenci görüşleri. Electronic Turkish Studies, $8(12)$. https://doi.org/10.7827/TurkishStudies.5623

Paino, P. (2001). Games students play. The Science Teacher, 68(4), 28-30.

Roger, T., \& Johnson, D. W. (1994). An overview of cooperative learning. In J. Thousand, A. Villa, \& A. Nevin (Eds.), Creativity and Collaborative Learning. Brookes Press: Baltimore.

Şahin, A. (2011). Türkçe öğretmeni adaylarının takım oyun turnuvaları tekniğinin uygulanmasına yönelik 
görüşleri. Ekev Akademi Dergisi, 46(1), 489-498.

Salam, A., Hossain, A., \& Rahman, S. (2015). Effects of using teams games tournaments (TGT) cooperative technique for learning mathematics in secondary schools of Bangladesh. Malaysian Online Journal of Educational Technology, 3(3), 35-45. https://doi.org/10.17583/redimat.2015.1519

Schniedewind, N., \& Davidson, E. (2000). Differentiating cooperative learning. Educational Leadership, 58(1), 24-27.

Sharan, Y., \& Sharan, S. (1990). Group investigation expands cooperative learning. Educational leadership, 47(4), 17-21.

Şimsek, U., \& Baydar, A. (2019). Impacts of Jigsaw and Teams-Games-Tournaments (TGT) on Social Studies Preservice Teachers' Epistemological Beliefs. International Online Journal of Education and Teaching, 6(2), 405-414.

Slavin, R. E. (1975). Teams-games-tournament: A student team approach to teaching adolescents with special emotional and behavioral needs. Johns Hopkins University, Baltimore. https://doi.org/10.1037/e425732004-001

Slavin, R. E. (1978). Using Student Team Learning. The Johns Hopkins Team Learning Project. Johns Hopkins University.

Slavin, R., \& Karweit, N. L. (1979). An extended cooperative learning experience in elementary school. US Department of Education Educational Resources Information Center.

Thanh Pham, T. H. (2013). Using group projects as a strategy to increase cooperation among low-and high-achieving students. Higher Education Research \& Development, 32(6), 993-1006. https://doi.org/10.1080/07294360.2013.806436

Thomas, T. A. (2014). Developing team skills through a collaborative writing assignment. Assessment \& Evaluation in Higher Education, 39(4), 479-495. https://doi.org/10.1080/02602938.2013.850587

Tombak, B., \& Altun, S. (2016). The effect of cooperative learning: University example. Eurasian Journal of Educational Research, 64, 173-196. https://doi.org/10.14689/ejer.2016.64.10

Topping, K. J. (2005). Trends in peer learning. Educational Psychology, 25(6), 631-645. https://doi.org/10.1080/01443410500345172

Uysal, E. (2010). A modeling study: The interrelationships among elementary students' epistemological beliefs, learning environment perceptions, learning approaches and science achievement (Doctoral dissertation, Middle East Techical University, Ankara).

Veloo, A., Md-Ali, R., \& Chairany, S. (2016). Using cooperative teams-game-tournament in 11 religious school to improve mathematics understanding and communication. Malaysian Journal of Learning and Instruction, 13(2), 97-123. https://doi.org/10.32890/mjli2016.13.2.4

Weiss, I., Kramarski, B., \& Talis, S. (2006). Effects of multimedia environments on kindergarten children's mathematical achievements and style of learning. Educational Media International, 43(1), 3-17. https://doi.org/10.1080/09523980500490513

Wodarski, J. S., \& Feit, M. D. (2011). Adolescent preventive health and team-games-tournaments: Five decades of evidence for an empirically based paradigm. Social work in public health, 26(5), 482-512. https://doi.org/10.1080/19371918.2011.533561

Yalçın, Y. (2008). Su dalgaları konusunun öğretiminde işbirlikli öğrenme yönteminin öğrenci başarısına etkisi. Yüksek lisans tezi. Dokuz Eylül Üniversitesi Eğitim Bilimleri Enstitüsü, İzmir.

Yeşilyurt, E. (2009). İşbirliğine dayalı öğrenmenin öğrenci davranışları üzerindeki etkisine ilişkin öğrenci görüşleri. Fırat Üniversitesi Sosyal Bilimler Dergisi, 19(2), 161-178.

Yıldırım, A., \& Şimşek, H. (2005). Sosyal bilimlerde nitel araştırma yöntemleri. Ankara: Seçkin Yayıncılık.

Zetty, N. (1992). A comparison of the STAD and Jigsaw cooperative learning methods in a college-level microcomputer applications course (Doctoral dissertation, West Virginia University, Morgantown). 


\section{Copyrights}

Copyright for this article is retained by the author(s), with first publication rights granted to the journal.

This is an open-access article distributed under the terms and conditions of the Creative Commons Attribution license (http://creativecommons.org/licenses/by/4.0/). 